\title{
Landslide research at the British Geological Survey: capture, storage and interpretation on a national and site-specific scale
}

\author{
PENNINGTON ${ }^{1}$, C. V. L., FOSTER, C., CHAMBERS, J. E. and JENKINS, G. O. \\ ${ }^{1}$ British Geological Survey, Keyworth, Nottinghamshire, NG12 5GG, UK \\ cpoulton@bgs.ac.uk Tel +44115936 3049 www.bgs.ac.uk/landslides
}

\begin{abstract}
Landslide research at the British Geological Survey (BGS) is carried out through a number of activities including surveying, database development and real-time monitoring of landslides. Landslide mapping across the UK has been carried out since BGS started geological mapping in 1835. Today, BGS geologists use a combination of remote sensing and ground-based investigations to survey landslides. The development of waterproof tablet computers (BGS-SIGMAmobile), with inbuilt GPS and GIS for field data capture provides an accurate and rapid mapping methodology for field surveys. Regional and national mapping of landslides is carried out in conjunction with site specific monitoring, using terrestrial LiDAR and differential GPS technologies, which BGS has successfully developed for this application. In addition to surface monitoring, BGS is currently developing geophysical ground-imaging systems for landslide monitoring, which provide real-time information on subsurface changes prior to failure events. BGS's mapping and monitoring activities directly feed into the BGS National Landslide Database, the most extensive source of information on landslides in Great Britain. It currently holds over 14,000 records of landslide events. By combining BGS's corporate datasets with expert knowledge, BGS has developed a landslide hazard assessment tool, GeoSure, which provides information on the relative landslide hazard susceptibility at national scale.
\end{abstract}

Key words: landslide, National Landslide Database, GeoSure, hazard, LiDAR, geophysics

\section{Introduction}

In the global context, Great Britain does not experience extreme climatic or tectonic events, nor have the mountainous regions associated with large scale, destructive landslides seen elsewhere in the world. Despite this, landslides are common in Britain and several major landslides have occurred within living memory. Examples of these have caused structural damage to property (Holbeck Hall, Scarborough; Lee, 1999), interrupted transportation routes (Glen Ogle, Scotland; Winter et al., 2006) and resulted in fatalities (Whitehaven, Cumbria; Jenkins and Hobbs, 2007).

The British Geological Survey (BGS) is the national geological agency for Great Britain that provides geoscientific information to government, other institutions and the public. This paper gives an overview of the research BGS is currently undertaking into landslides on both national and site-specific scales with emphasis on new technologies.

\section{National-scale landslide assessments of Great Britain}

To reduce the risks associated with unstable ground to the public, the identification of both known failures and possible future landslides is vital. With rising population, pressures on land and climate change the identification of landslides, and the potential for them, is of particular significance.

\subsection{The BGS National Landslide Database}

Prior to a national assessment of landslides being undertaken, the subdued topography and degraded nature of many ancient failures meant that landsliding was not considered to be widespread or problematic in Great Britain. However, costly disruptions to projects in the 1960s such as the Sevenoaks Road By-pass (Skempton and Weeks, 1976) and the Waltons Wood motorway embankment (Early and Skempton, 1974) by reactivations of previously unknown landslides led to the realisation that research was needed to determine the significance and extent 


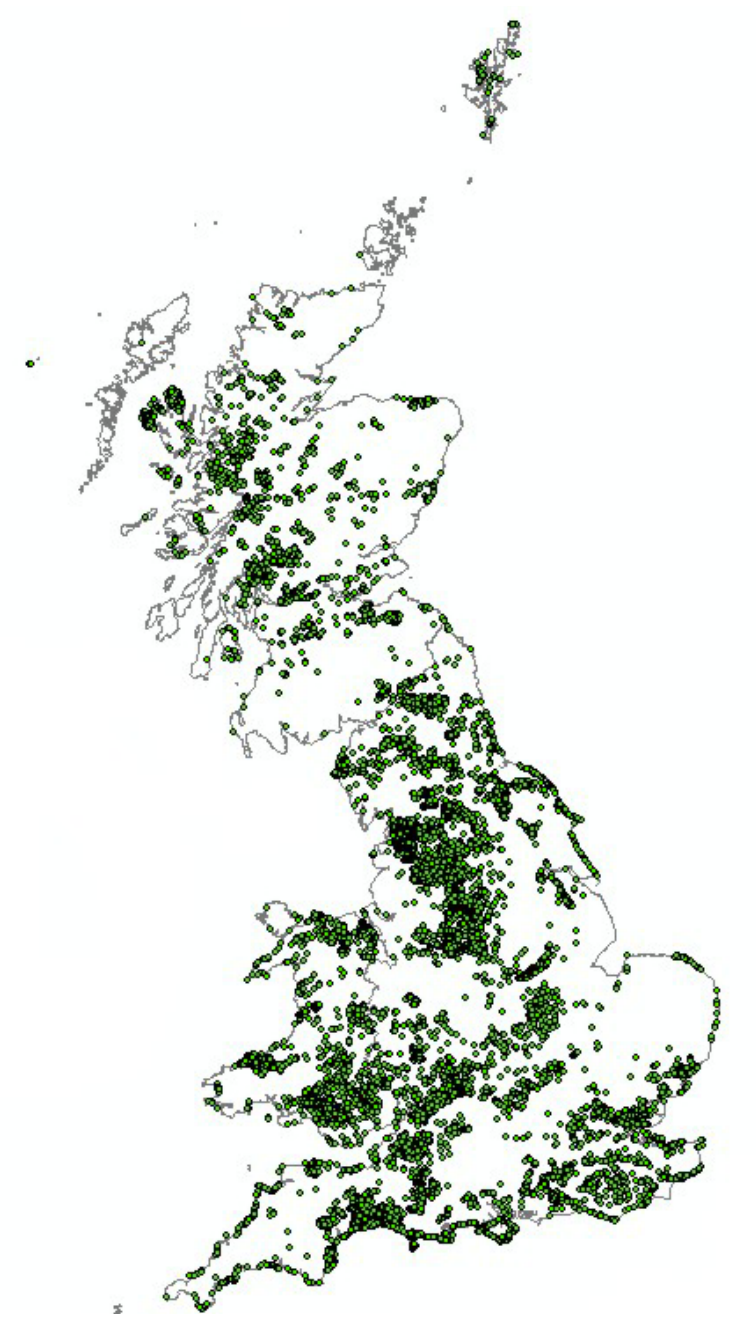

Figure 1 Current distribution of landslides held in the National Landslide Database of the problem. Between 1985 and 1990, a desk study was commissioned by the Department of the Environment (DoE) to establish the extent and significance of landsliding in Great Britain. This involved researching all possible sources of information including reports, journals and BGS published geological maps and memoirs. Since 1995, the DoE database has been incorporated into, and superseded by, the BGS National Landslide Database.

The National Landslide Database has been developed by BGS and is, to date, the most comprehensive source of information on landslides in Great Britain. It currently holds over 14,000 records of landslide events with each landslide documented as fully as possible (Figure 1). Each landslide record can hold information on over 35 attributes including location, dimensions, landslide type, trigger, damage caused, slope aspect, material, movement date, vegetation, hydrogeology, age, development and a full bibliographic reference.

The database draws together information from many resources, generally only available to and known about by specialists, for use by the public and practitioners. Data come from a variety of sources including published BGS geological maps and revision surveys. Other sources include commissioned and research studies and a number of regional databases inherited or compiled by BGS since the 1970s. The information is corporately maintained and held in digital format that can be adapted and updated so it will be useable for decades to come. The database is linked to a GIS which displays the landslides as point data. The BGS Landslides Team is currently working towards making selected information from the database freely available through the GeoIndex, the BGS online GIS.

\subsection{National landslide hazard and susceptibility map: GeoSure}

GeoSure was developed by BGS as a digital landslide hazard assessment of the British mainland; Error! Reference source not found. is a simplified map of the GeoSure dataset.

GeoSure was derived using a methodology, which combined both heuristic and deterministic assessment. The heuristic approach used expert judgement to assess and classify the susceptibility of hazard, and determined the geological and topographical conditions likely to cause landsliding (Soeters and Van Westen, 1996). The deterministic approach assessed these causative factors and gave each one a rating according to their relative importance in causing slope instability. The most important controlling factors of landsliding in Great Britain were identified as slope angle, hydrogeology, climate and the presence of discontinuities. After several iterations, three key factors were used - slope, geology and bedrock discontinuities: 
A slope model was derived directly from the NEXTMap ${ }^{\mathrm{TM}}$ digital terrain model of Britain. The NEXTMap ${ }^{\mathrm{TM}}$ dataset was generated from an airborne survey and the one that was used has a $5 \mathrm{~m}$ resolution. This resolution was considered too detailed and too memory intensive for nationwide use, so it was resampled to $25 \mathrm{~m}$ for use in GeoSure.

Digital geological polygons were assigned a score defining the potential of that material to fail. The score is based on an additive algorithm that incorporates material strength, permeability and known susceptibility to instability of different lithologies, combined with slope angle. The geological data was based upon geotechnical data, literature reviews and specialist geological expertise.

Discontinuities influence the strength of a material, its susceptibility to failure and its ability to allow water to penetrate a rock mass. Detailed information about rock discontinuities was not consistently available for the majority of rock types in Britain. Therefore categories were defined in line with those used in the British Standard 5930: Field Description of Rocks and Soils (British Standards Institute, 1990) and by Bieniawski (1989).

The methodology applied is flexible enough to allow alteration of the algorithm in the future (nationally or locally) and includes other factors such as the presence and nature of superficial deposits. Once all the contributing factors were identified, they were combined using a multicriterion technique. The multicriterion approach applied a series of rules against the available data to provide a susceptibility 'score' for each location in Britain. A high score does not necessarily mean that the landslide has happened in the past or will do so in the future but that the conditions mean there is a potential for future landsliding.

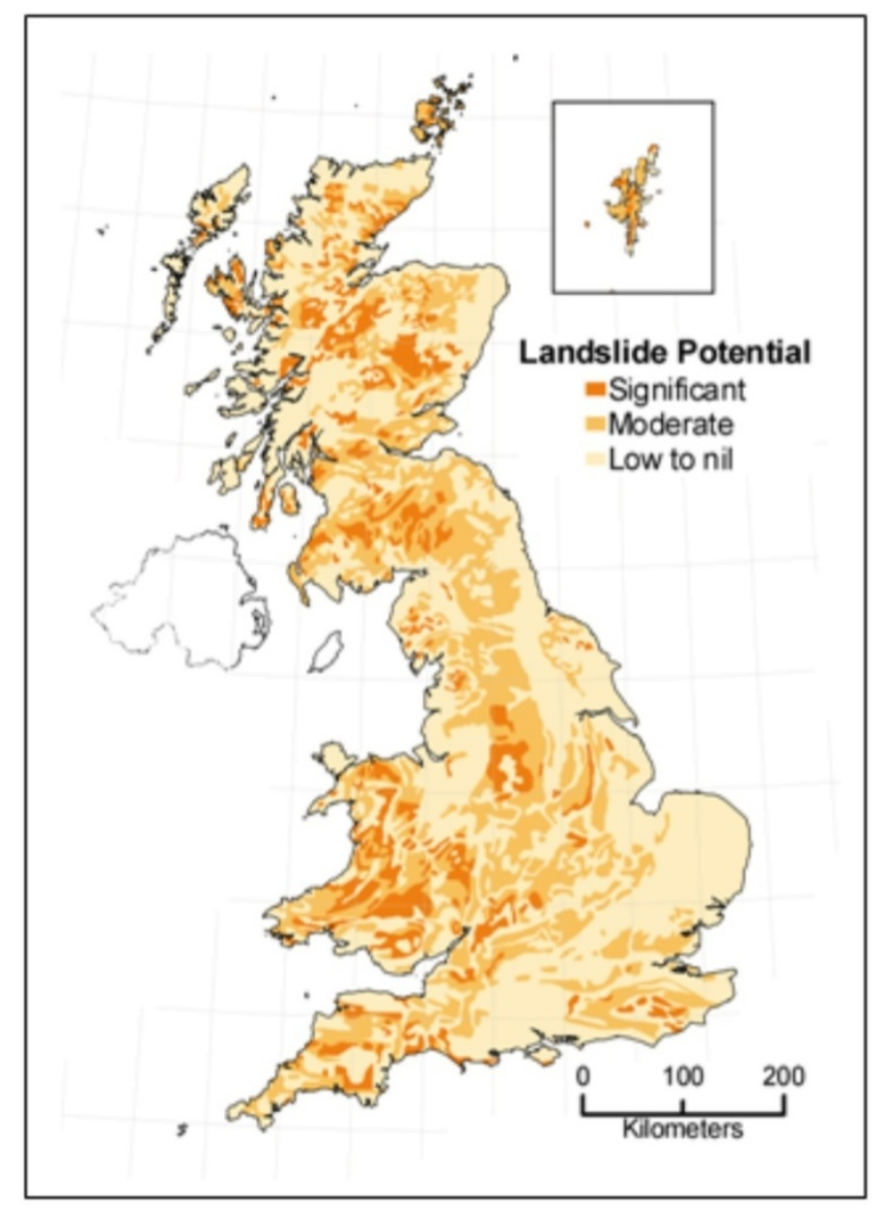

Figure 2 Simplified map of GeoSure

\subsection{New landslide mapping techniques}

National-scale landslide mapping has been carried out in the UK since BGS started geological mapping in 1835. Today, BGS geologists use a combination of remote sensing and field interpretation to survey landslides.

BGS-SIGMAmobile is the BGS digital field data capture system running on rugged tablet PCs with integrated GPS units and used as standard for all geological mapping activities (Jordan et al., 2008). The development of this technology has provided an accurate and rapid mapping methodology for field surveys and has enabled digital data to be directly collected and interrogated by GIS in the field. Geologist are able to create accurate geological and geomorphological maps in the field, capture landslide information that is directly linked to the National Landslide Database, make digital sketches and take photographs, which are all linked to corporate datasets. 


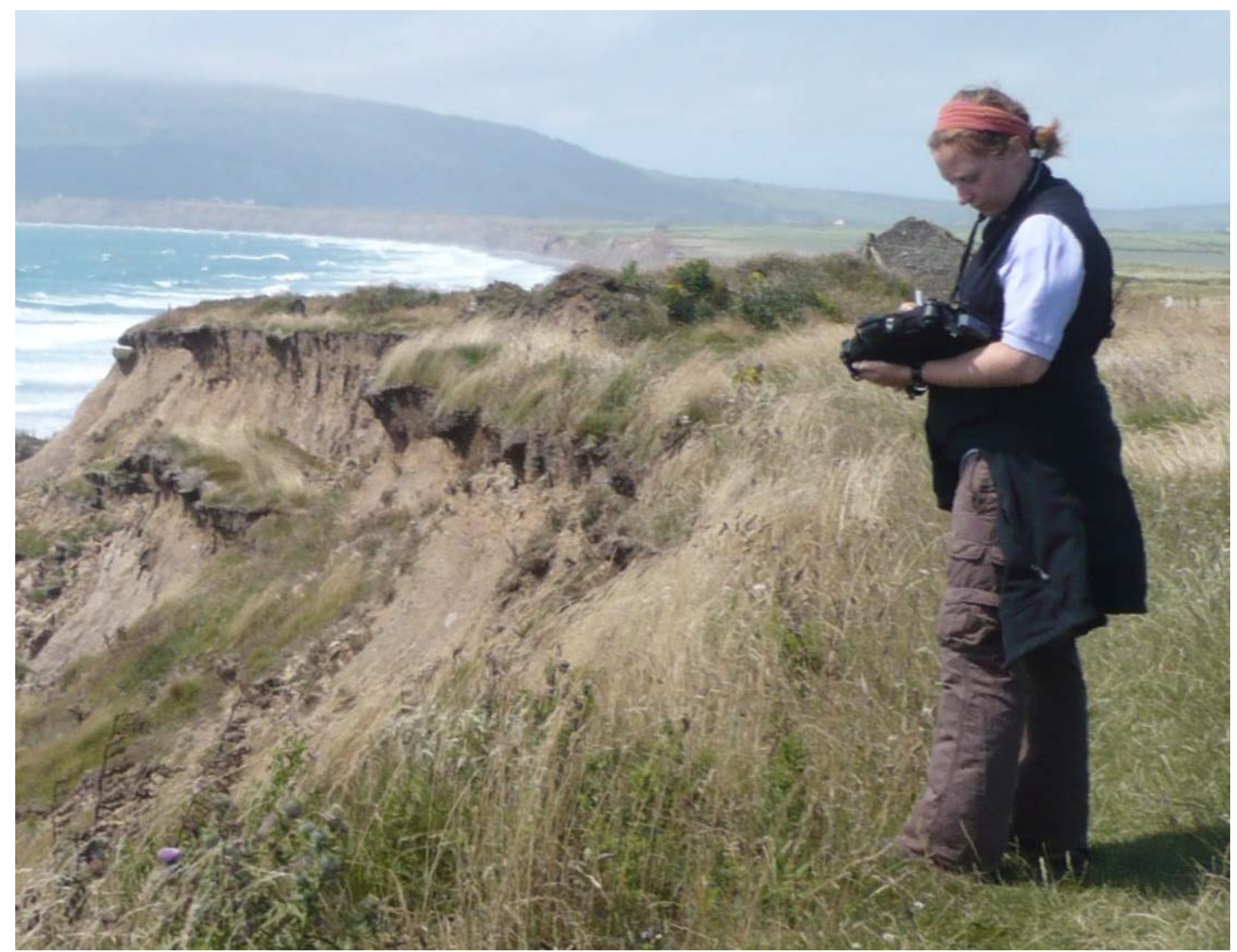

Figure 3 BGS•SIGMAmobile being used in the field

\section{Landslide observatory case study: Hollin Hill, Yorkshire, UK}

The Hollin Hill landslide is located in the north of England in Yorkshire (Figure 4). It is located in a glacial outwash valley, on the south facing side with a slope of approximately $12^{\circ}$. The unstable ground extends for a distance of $200 \mathrm{~m}$ down the slope, and for a width of several hundred metres.

The landslide is currently active and scientific research at this site has been designed to enable BGS to accurately monitor and eventually predict movement of the landslide. It brings together a combination of field surveying, geomorphological, geophysical, engineering and hydrogeological expertise at BGS.

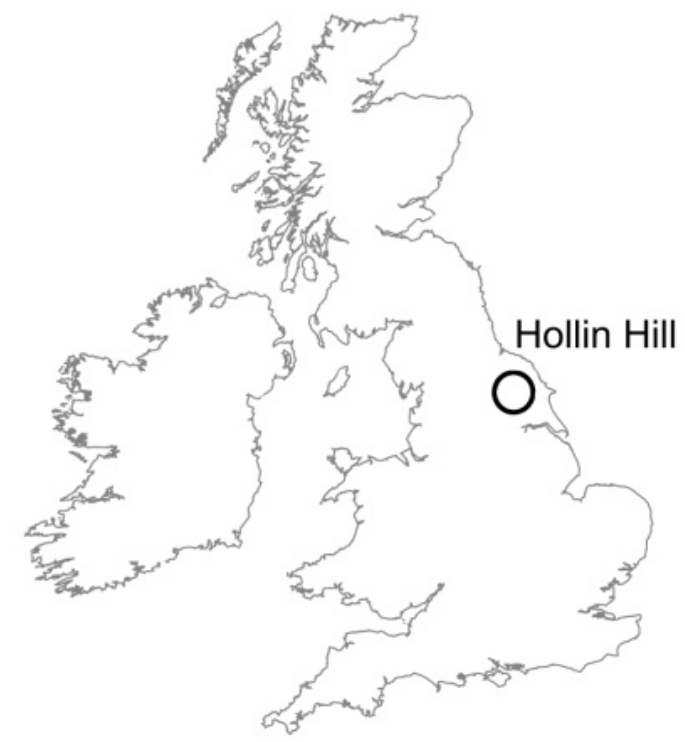

Figure 4 Location map of the Hollin Hill landslide observatory, Yorkshire, UK 


\subsection{Geology}

The geology of the Hollin Hill landslide (Figure 5) comprises a Jurassic sequence from the Redcar Mudstone Formation at the base, with an outcrop of the Staithes Sandstone Formation running across the middle section of the slope. The Whitby Mudstone Formation overlies this, with the upper part of the slope composed of the Dogger Formation.

The Redcar Mudstone Formation forms the base of the Lias Group and comprises up to $200 \mathrm{~m}$ of mainly dark grey mudstones and siltstones; subsidiary thin limestones (concentrated in the lower third), very fine grained sandstones, and sideritic and 'chamositic' ironstone beds and nodules are also present (Powell, 1984).

The Staithes Sandstone Formation (Middle Lias) comprises approximately $20 \mathrm{~m}$ of fossiliferous, micaceous, calcareous, very fine- to fine-grained sandstone. It is yellow-brown at outcrop but grey when fresh with interbedded grey siltstone and silty mudstone.

The Whitby Mudstone Formation, which forms the upper part of the Lias Group, typically consists of bluish grey to dark grey, sparsely fossiliferous, fissile, locally bituminous mudstones and siltstones. Bands of calcareous concretions are common at some horizons. At its thickest, it reaches about 25-30m thickness in the study area.

The Dogger Formation is composed of a massive, fine to medium-grained calcareous sandstone, up to 2.7 metres in thickness (Gaunt et al., 1980). The Dogger Formation forms an extensive flat plateau behind the slope of Hollin Hill.

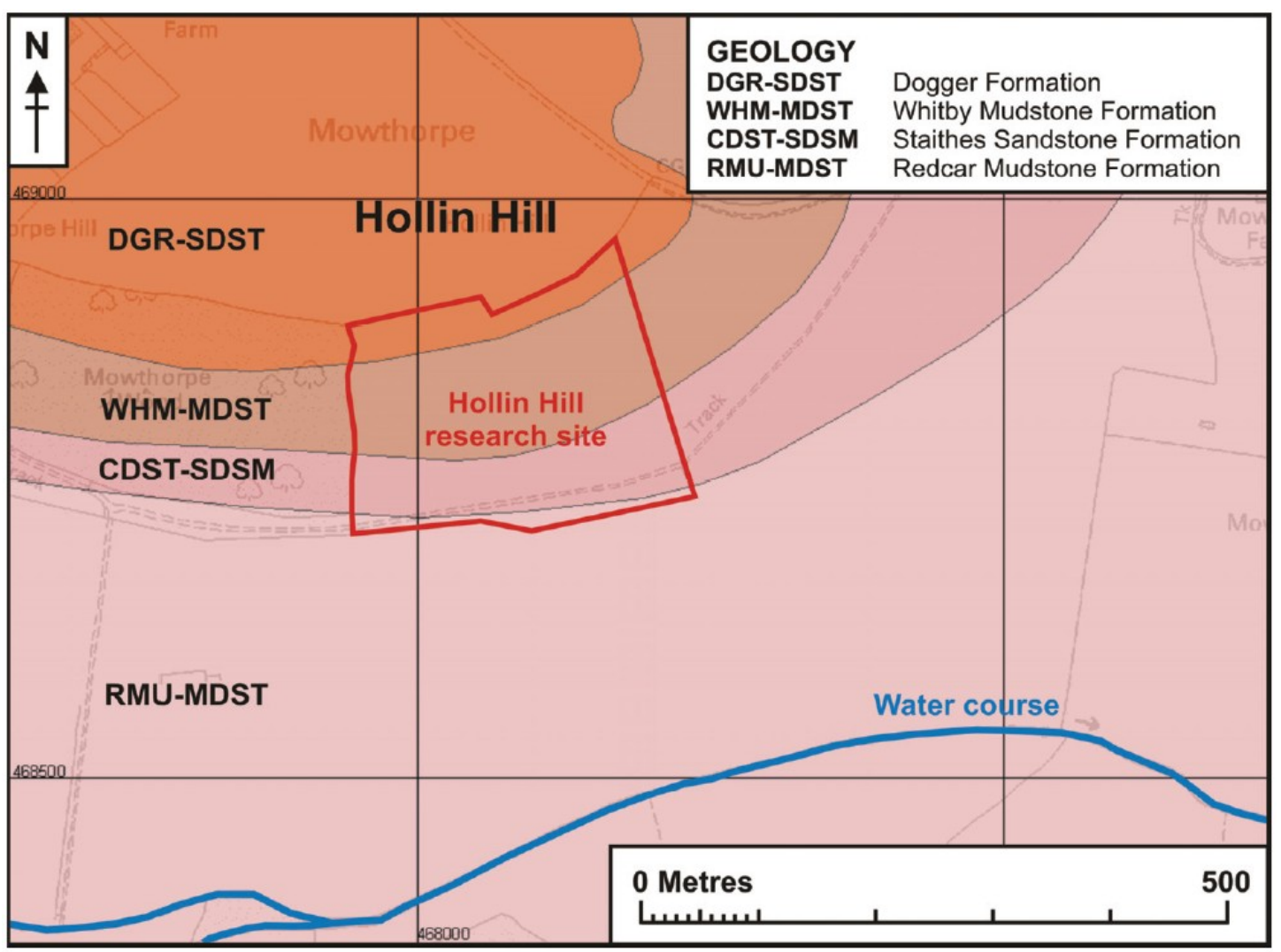

Figure 5 Geological map of the Hollin Hill research site (Geological map, BGS ㄷ NERC 2009. Base map, Ordnance Survey (C) Crown copyright. All rights reserved. Licence number 100017897/2009). 


\subsection{Landslide}

The instability of the slope at Hollin Hill is largely controlled by the geology, particularly the Whitby Mudstone Formation, which is highly prone to landsliding (Jenkins et al., 2005). Figure 6 shows part of the landslide where several landslide features can be distinguished.

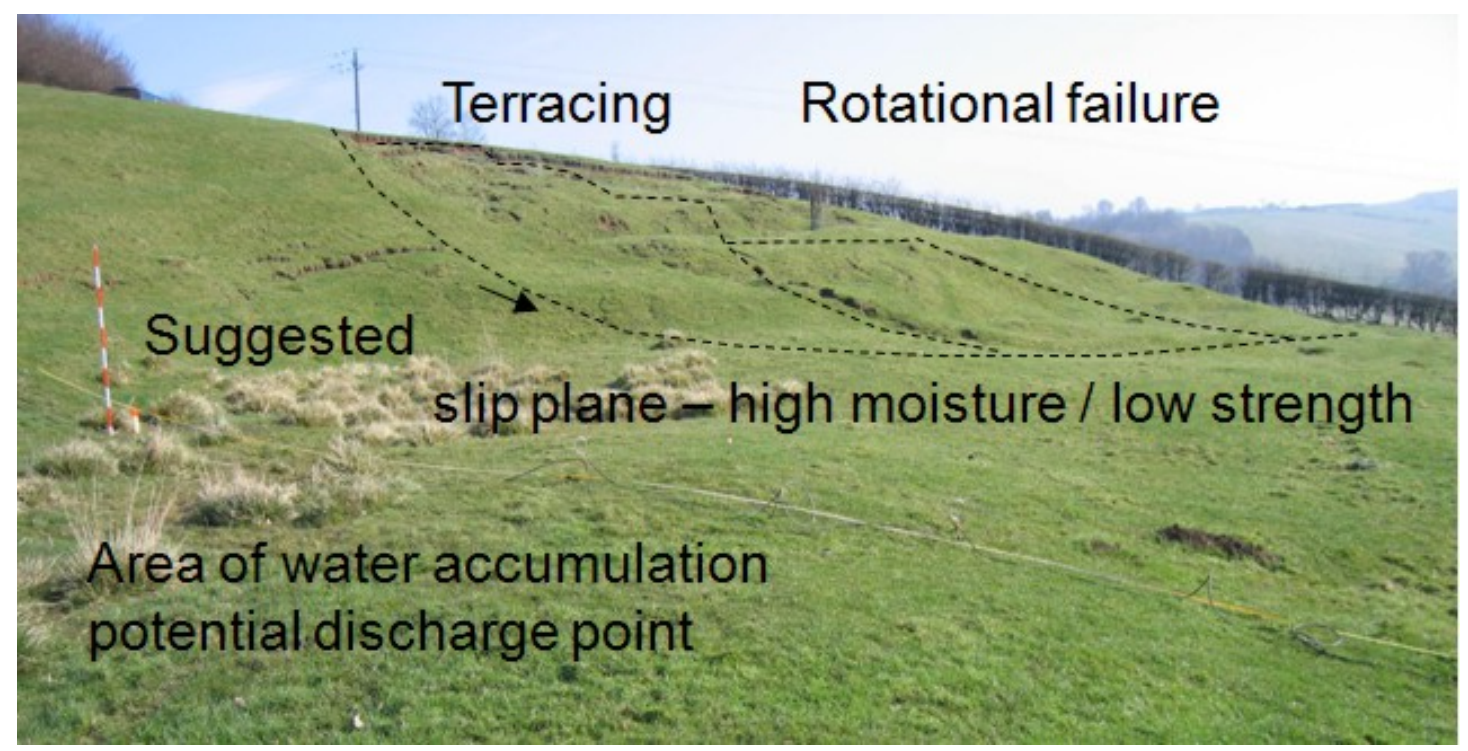

Figure 6 Annotated photograph of part of the Hollin Hill landslide

This slope forms a complex landslide according to the classifications by Varnes (1978), the IAEG Commission on Landslides (1990), the Working Party on World Landslide Inventory (WP/WLI, 1990; 1993and Cruden and Varnes (1996). It is characterised by shallow rotational failures at the top of the slope in the Whitby Mudstone Formation, which move through an area of translational landslide movement and "cascades" over the in situ Staithes Sandstone Formation feeding into four larger-scale flow-lobes at the bottom of the slope (Figure 7). In recent years, annual movement of the lobes has been in the order of tens of centimetres. The morphology of the slope is complex with numerous isolated shallow failures and slumping. Locally the slope becomes very steep where slipped material has accumulated to form lobes.

Movement typically occurs in the winter months (i.e. January and February) when the slope is at its wettest. During this period water can be observed accumulating in the basins caused by rotational slips towards the top of the slope, and can be seen emerging from the front of the lobes. A spring line also extends across the base of the slope where the Staithes Sandstone gives way to the underlying Redcar Mudstone Formation. Runoff from the valley floor and sides appears to drain into the stream located at the valley centre (Chambers et al., 2008). 


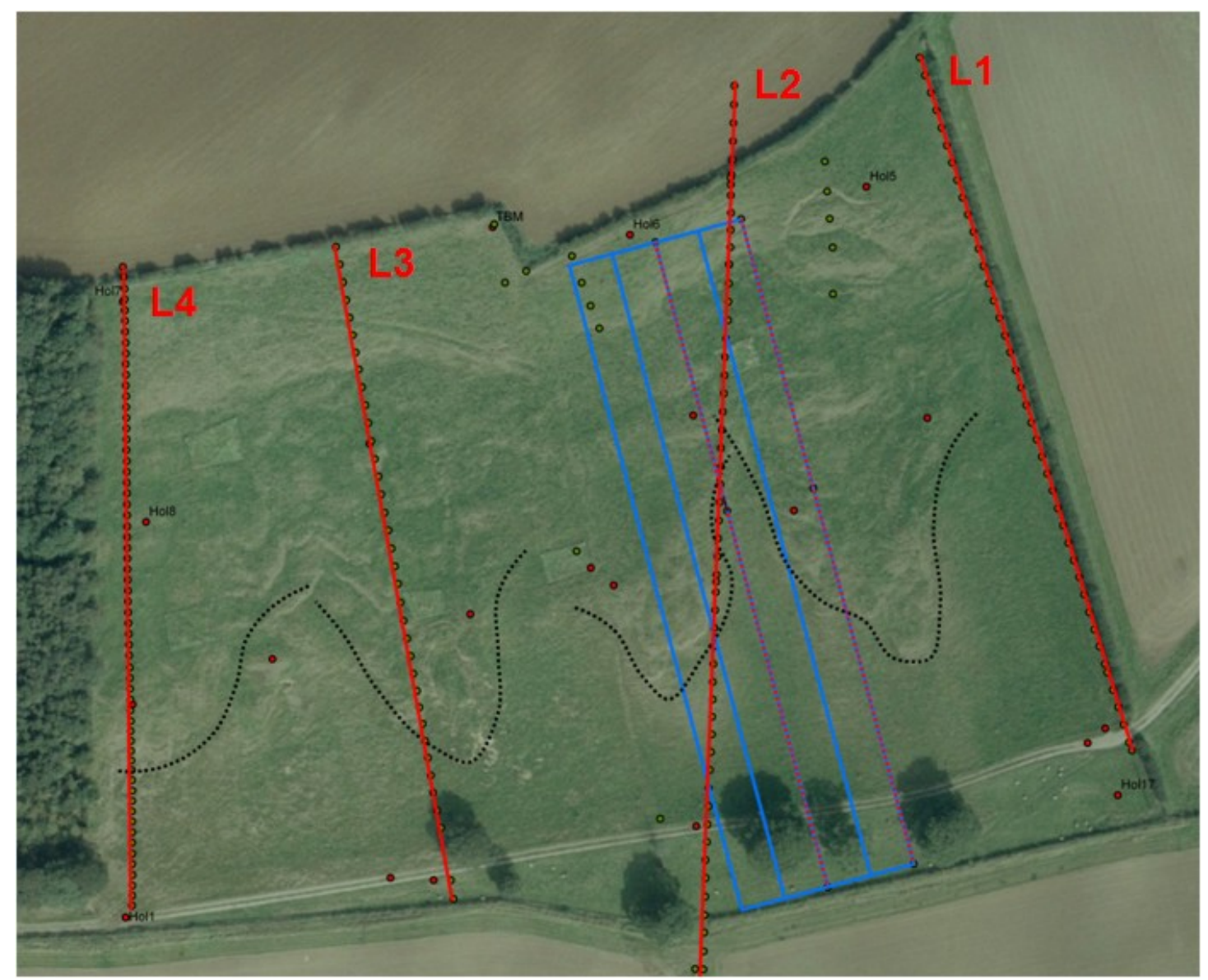

Figure 7 Hollin Hill geophysics survey plan (CUKP/Getmapping Licence No UKP/2009/01). Black dotted lines indicate lobe features.

\subsection{Methodology}

BGS is monitoring the site using a combination of several new technologies including geological, hydrogeological, geomorphological and geophysical expertise. The overarching objective of the research is to develop a $4 \mathrm{D}$ landslide monitoring system that can characterise the subsurface structure of the landslide, and reveal the hydraulic precursors to movement. The movement is then captured using surveying techniques.

\subsubsection{LiDAR}

Both aerial and terrestrial LiDAR surveys have been carried out at this site. These have provided BGS with the unique opportunity to appraise the relative merits of the different technologies and their application monitoring an active landslide site in the United Kingdom.

The first (baseline) survey recorded the ground surface of the landslide and surrounding slope area in three-dimensions. Subsequent surveys of this active landslide will record the movement of the slope. Terrestrial surveys are carried out at twelve-monthly intervals and the data collected in the field by LiDAR and differential GPS are entered into a computer-modelling package (Figure 8). The results are processed to provide data to model the way in which the landslide is moving. Information obtained by the Terrestrial LiDAR survey will allow the changing shape of the surface to be monitored. 


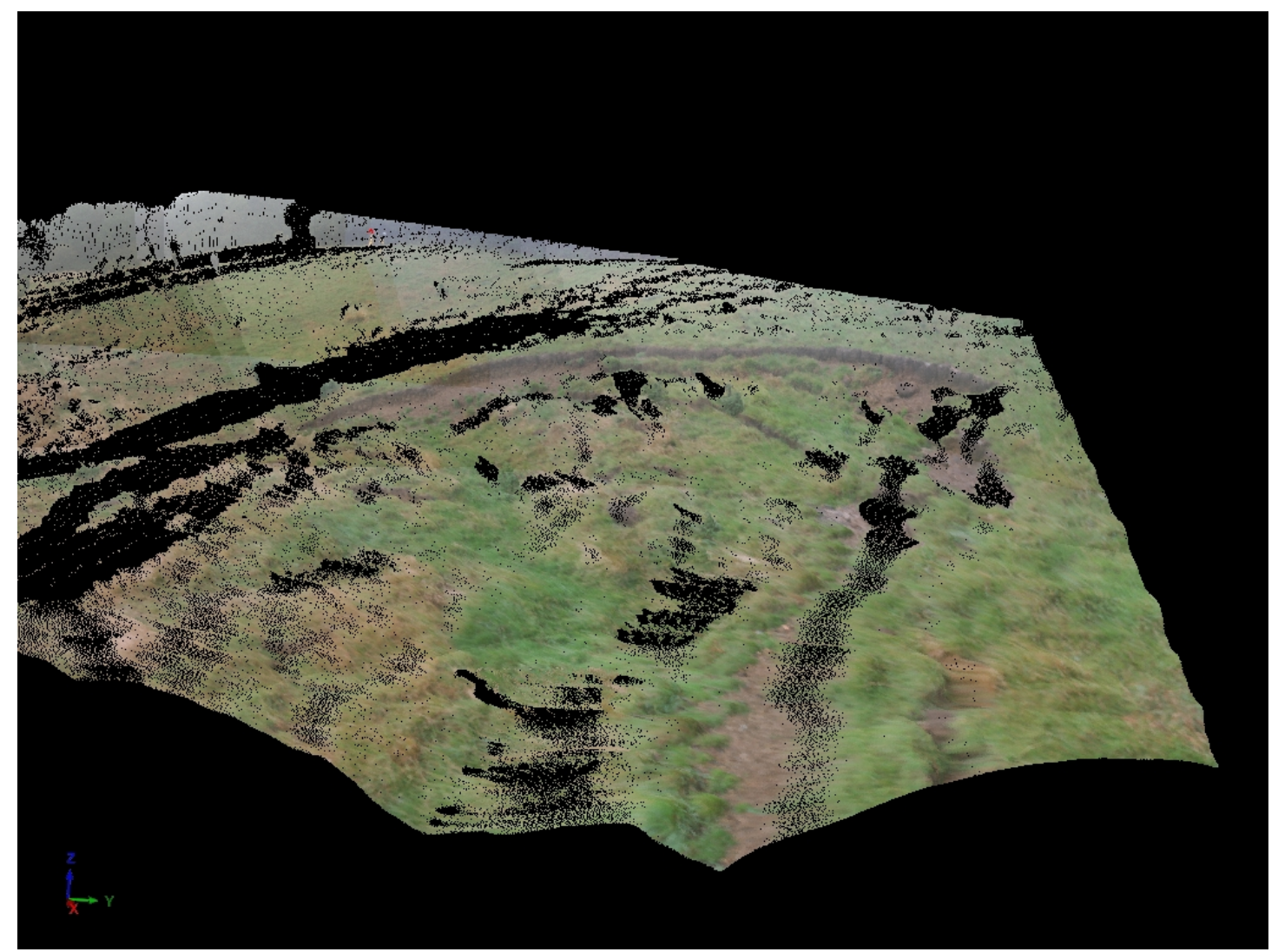

Figure 8 Point cloud array from terrestrial LiDAR scan captured in 2007. The rear scar of a rotated block at the top of the slope can be seen here.

\subsubsection{Geophysics}

Geophysical techniques are playing an increasingly important role in the investigation and monitoring of landslides (e.g. Jongmans and Garambois, 2007); such methods are proving to be particularly effective for revealing the 3D structure, failure surfaces, and the hydrogeological regimes associated with landslides. Geoelectrical techniques, such as resistivity and self-potential, are particularly applicable to the study of hydraulic processes associated with landslides (Jomard et al., 2007). The great strengths of these techniques are that they provide spatial or volumetric information at the site scale, and are sensitive to hydraulic changes in the subsurface.

Geophysical investigation of this site enables the study of any movement of the landslide in three dimensions and provides geophysical data across the whole of the Hollin Hill research site. The following geophysical techniques were used: Geocarta mobile resistivity mapping; Electrical Resistivity Tomography (ERT) lines (2D) and grids (3D); Self Potential (SP) profiles (2D) and grids (3D). Figure 7 shows the geophysical survey plan. The primary focus of the ongoing research is to use time-lapse ERT and SP to characterise subsurface structure (e.g. Friedel et al., 2006); and to monitor hydrogeological changes (i.e. water table (e.g. Revil et al., 2003), moisture content, seepage pathways), and investigate the link between these changes and the movement of the landslide (e.g. Perrone et al., 2004).

In the spring of 2008, an automated time-lapse electrical resistivity tomography (ALERT) system was permanently installed on the site (Kuras et al., 2009; Ogilvy et al., 2009). The ALERT instrument uses wireless telemetry (in this case GPRS) to communicate with an office based PC, which runs control software and a database management system. The control software schedules data acquisition, whilst the database management system stores, processes and inverts the remotely streamed ERT data. Once installed and configured, the system operates autonomously without manual intervention. Modifications to the ALERT system at this site have included the 
addition of environmental and geotechnical sensors to monitor rainfall, ground movement and pore pressure changes within the landslide (Figure 9). The system is housed in a weatherproof enclosure and is powered by batteries charged by a wind turbine $\&$ solar panels.

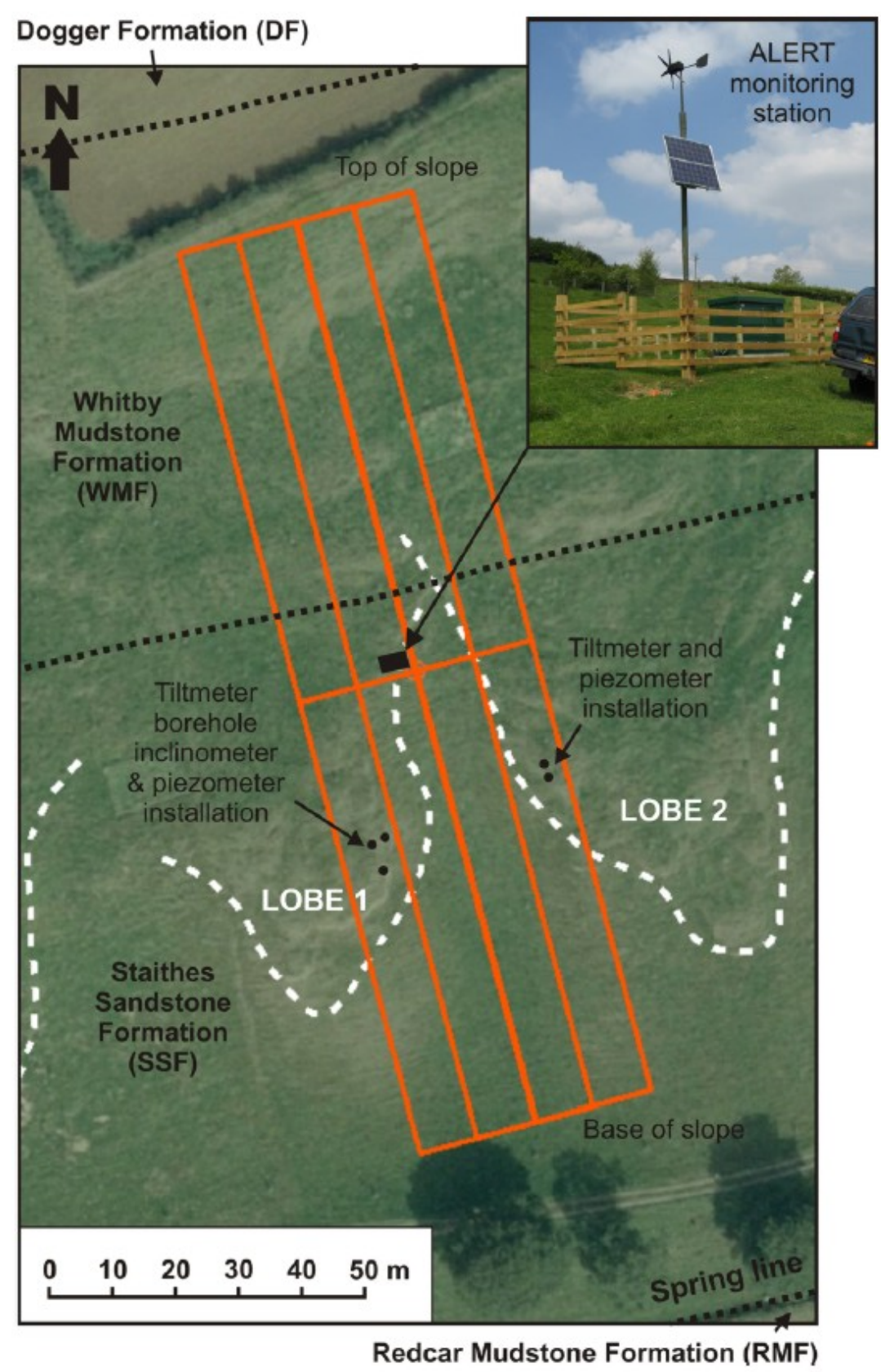

Figure 9 Site plan showing the location of the ALERT station, ERT monitoring arrays (red lines), major geomorphologic features (white-dashed lines) and bedrock geology (black dashed lines). (৫ UKP/Getmapping Licence No. UKP2008/01)

\subsection{Preliminary results}

Good resistivity contrasts between the slipped material and sandstone bedrock has allowed us to use resistivity mapping data and ERT models to define the geometry of the landslide. The resistivity map revealed the extent of the in-situ and slipped Whitby Mudstone Formation (low resistivity), and in-situ Staithes Sandstone (high resistivity). These data were complemented by the ERT models in which the lobes of slipped mudstone could be distinguished from the underlying sandstone bedrock; in particular, slip surfaces can be seen in the resistivity models where the mudstone lobe has overridden the sandstone bedrock (Figure 10). 

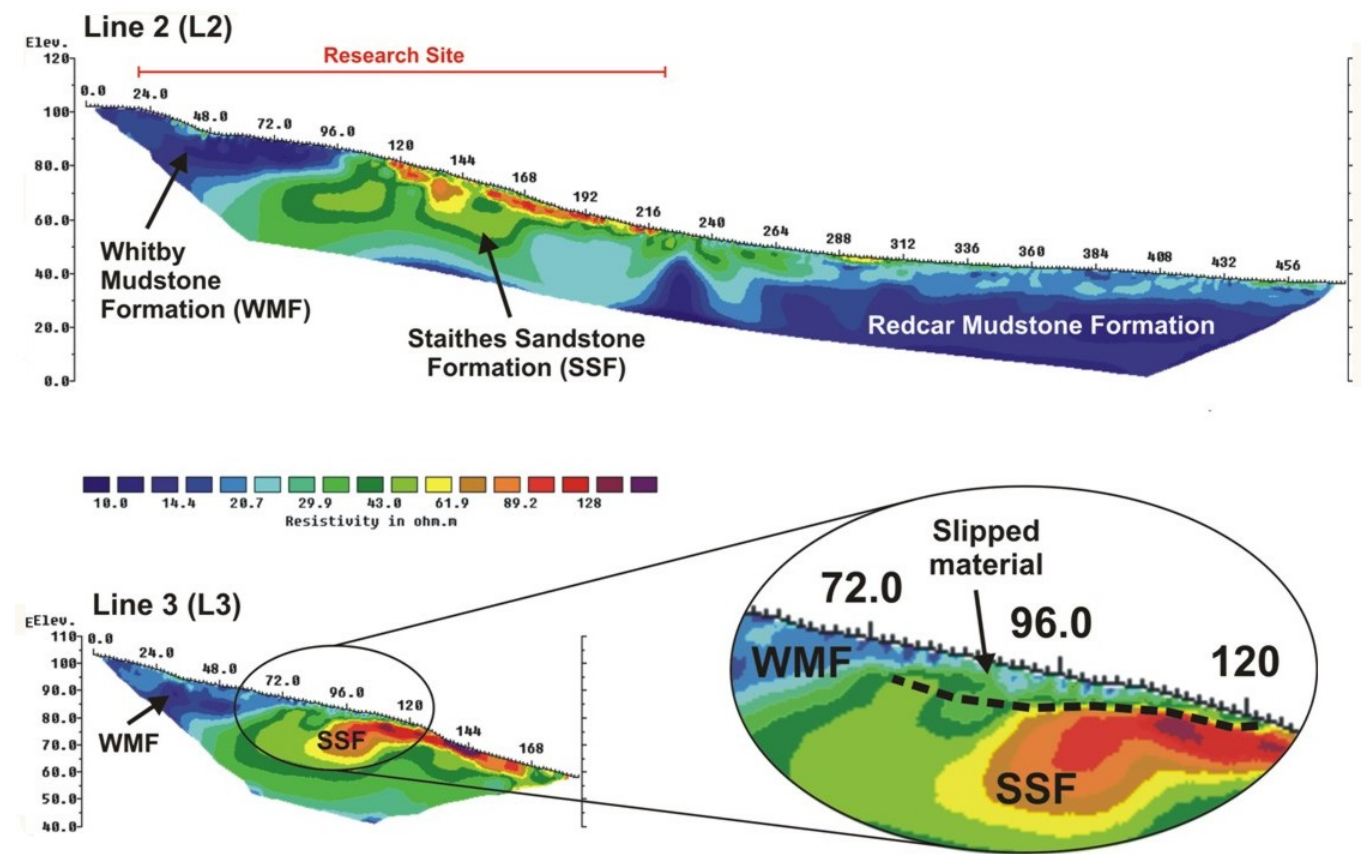

Figure 10 2D ERT model and SP profile

A static 3D ERT model was generated from data collected shortly after the ALERT system was installed (Figure 11). This model shows the three-dimensional structure of the landslide and is the reference model for future models to be measured against. The geology of the hillslope is clearly distinguished in the model: the Whitby Mudstone Formation (WMF) is a clay rich low resistivity formation (green-blue); the Staithes Sandstone Formation (SSF) has lower clay content and is more resistive (pink-white); the underlying Redcar Mudstone Formation (RMF) displays a similar resistivity range to that of the WMF (green-blue). The slipped WMF material of lobes 1 and 2 is clearly seen to override the SSF bedrock. Detailed analysis of the resistivity image has revealed variations in lobe thickness across the imaging area, which has subsequently been confirmed through intrusive investigations (i.e. drilling, augering, and cone penetration tests).

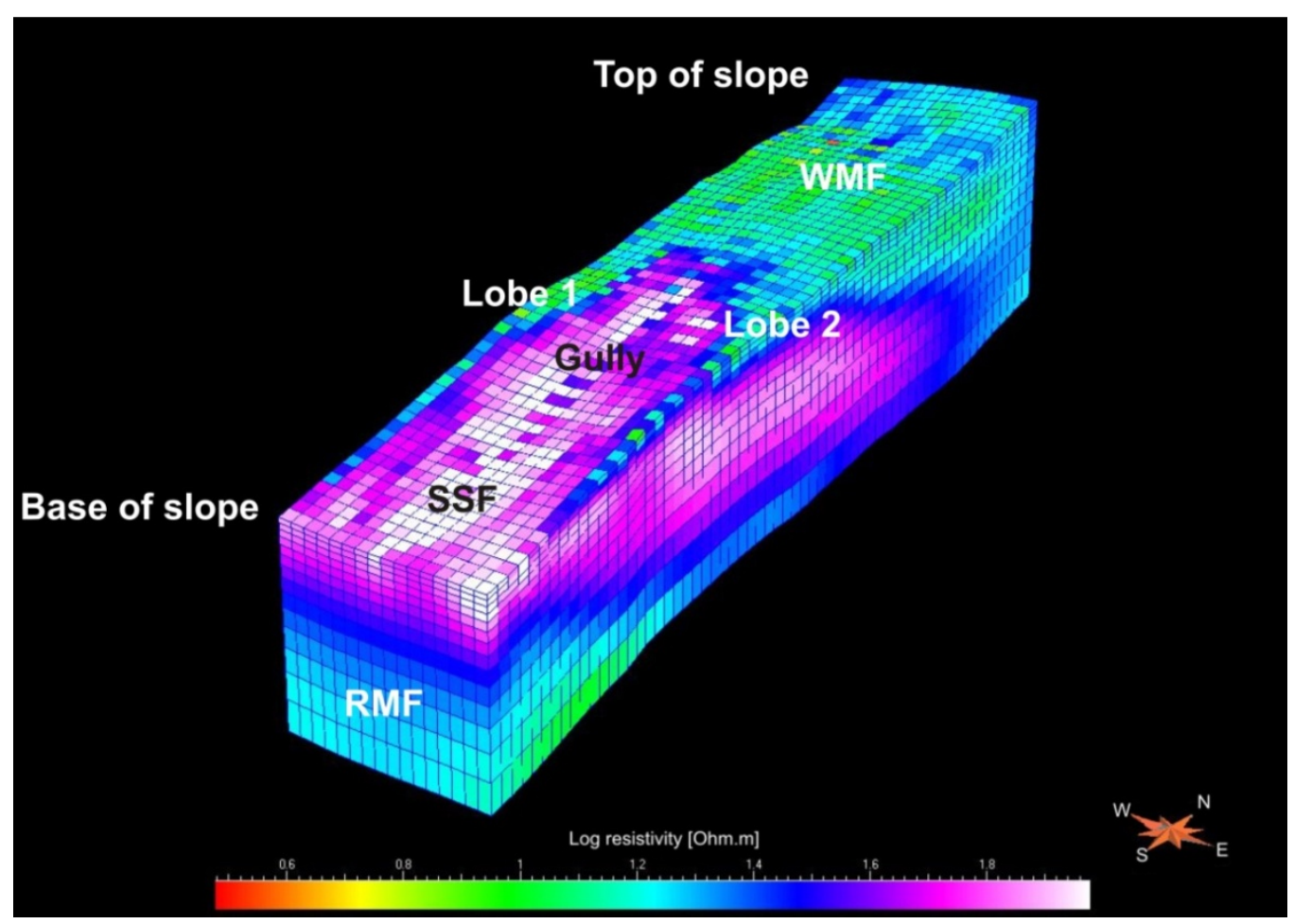

Figure 11 Baseline 3D ERT model of the landslide generated from ALERT data. 


\section{Conclusion}

This paper has provided an overview of the integrated scientific research BGS is carrying out and outlined some of the technology and methodologies used to collect data for interpretation.

\section{Acknowledgements}

These research results are part of a project financially supported by the Natural Environment Research Council (NERC). The authors would like to thank to Dr Anthony Cooper, Peter Hobbs and Dr Helen Reeves. This paper is published with the permission of the Executive Director of the British Geological Survey (NERC).

\section{References}

Bieniawski, Z.T., 1989, Engineering Rock Mass Classifications, Wiley Interscience, New York.

British Standards Institute, 1990, BS 5930. The Code of practice for site investigations, HMSO, London.

Chambers, J.E., Weller, A.L., Gunn, D.A., Kuras, O., Wilkinson, P.B., Meldrum, P.I., Ogilvy, R.D., Jenkins, G.O., Gibson, A.D., Ford, J.R., and Price, S.J., 2008, Geophysical anatomy of the Hollin Hill landslide, North Yorkshire, UK, Near Surface 2008 : 14th European Meeting of Environmental and Engineering Geophysics.

Cruden, D.M., and Varnes, D., 1996, Landslide types and processes, Special Report 247: Landslides: Investigation and Mitigation: Washington D.C., Transportation Research Board.

Early, K.R., and Skempton, A., 1974, Investigation of the landslide at Waltons Wood, Staffordshire: Quarterly Journal of Engineering Geology and Hydrogeology, v. 7, 101-102

Friedel, S., Thielen, A., and Springman, S.M., 2006, Investigation of a slope endangered by rainfall-induced landslides using 3D resistivity tomography and geotechnical testing: Journal of Applied Geophysics, v. 60, 100-114.

Gaunt, G.D., Ivemy-Cook, H.C., Penn, I.E., and Cox, B.M., 1980, Mesozoic rocks proved by IGS boreholes in the Humber and Acklam areas, Report of the Institute of Geological Sciences, 79/13.

IAEG Commission on Landslides, 1990, Suggested nomenclature for landslides Bulletin of the International Association of Engineering Geology (41), p. 13-16.

Jenkins, G.O., and Hobbs, P.R.N., 2007, Report of walkover survey and desk study of the South Beach landslide, Whitehaven Cumbria, British Geological Survey Report IR/07/002.

Jenkins, G.O., Jones, L.D., and Gibson, A., 2005, Analysis of the Hollin Hill Landslide, Low Mowthorpe, North Yorkshire : field reconnaissance survey and proposed survey recommendations, British Geological Survey, report IR/06/110 Nottingham, UK.

Jomard, H., Lebourg, T., Binet, S., Tric, E., and Hernandez, M., 2007, Characterization of an internal slope movement structure by hydrogeophysical surveying: Terra Nova, v. 19, 48-57.

Jongmans, D., and Garambois, S., 2007, Geophysical investigation of landslides : a review: Bulletin De La Societe Geologique De France, v. 178, 101-112.

Jordan, C.J., Howard, A.S., and Bee, E., 2008, The British Geological Survey digital field data capture system: better than pen and paper?, Proceedings of the 33rd International Geological Congress: Oslo. 
Kuras, O., Pritchard, J., Meldrum, P.I., Chambers, J.E., Wilkinson, P.B., Ogilvy, R.D., and G.P, W., 2009, Monitoring hydraulic processes with Automated time-Lapse Electrical Resistivity Tomography (ALERT): Comptes Rendus Geosciences - Special Issue on Hydrogeophysics (in press).

Lee, E.M., 1999, Coastal planning and management: the impact of the 1993 Holbeck Hall landslide, Scarborough: East Midlands Geographer, v. 21, 78-91.

Ogilvy, R.D., Kuras, O., Meldrum, P.I., Wilkinson, P.B., Chambers, J.E., Sen, M., Pulido-Bosch, A., Gisbert, J., Jorreto, S., Frances, I., and Tsourlos, P., 2009, Automated Monitoring of Coastal Aquifers with Electrical Resistivity Tomography. . Near Surface Geophysics (in press).

Perrone, A., Iannuzzi, A., Lapenna, V., Lorenzo, P., Piscitelli, S., Rizzo, E., and Sdao, F., 2004, High-resolution electrical imaging of the Varco d'Izzo earthflow (southern Italy): Journal of Applied Geophysics, v. 56, 17-29.

Powell, J.H., 1984, Lithostratigraphic nomenclature of the Lias Group in the Yorkshire basin: Proceedings of the Yorkshire Geological Society, v. 45, (1-2), p. 51-57.

Revil, A., Naudet, V., Nouzaret, J., and Pessel, M., 2003, Principles of electrography applied to self-potential electrokinetic sources and hydrogeological applications: Water Resources Research, v. 39, (SBH 3-1), p.

Skempton, A., and Weeks, A., 1976, The Quaternary history of the Lower Greensand escarpment and Weald Clay vale near Sevenoaks, Kent: Philosophical Transactions of the Royal Society A, v. 283, 493-526.

Soeters, R., and Van Westen, C.J., 1996, Slope instability recognition, analysis and zonation, Special report 247 Transportation Research Board: Washington DC, National Research Council, National Academy Press, p. 129-173.

Varnes, D., 1978, Slope movement types and processes, Special report 176: Landslides: Analysis and Control: Washington DC, Transportation Research Board.

Winter, M.G., Heald, A.P., Parsons, J.A., Shakman, L., and Macgregor, F., 2006, Scottish debris flow events of August 2004: Quarterly Journal of Engineering Geology and Hydrogeology v. 39, 73-78.

WP/WLI, 1990, International Geotechnical Societies' UNESCO Working Party on World Landslide Inventory (Chairman: DM Cruden): A suggested method for reporting a landslide: Bulletin of the International Association of Geoengineering properties and processes, v. 41, 5-12.

WP/WLI, 1993, International Geotechnical Societies' UNESCO Working Party on World Landslide Inventory (Chairman: DM Cruden): A suggested method for describing the activity of a landslide: Bulletin of the International Association of Geoengineering properties and processes, v. 47, 53-57 